\title{
Whole Genome Amplification by T7-Based Linear Amplification of DNA (TLAD): I. CIP Treatment of Samples and Tailing Reaction with Terminal Transferase
}

\author{
Chih Long Liu, Bradley E. Bernstein, and Stuart L. Schreiber
}

This protocol was adapted from "DNA Linear Amplification," Chapter 7, in Whole Genome Amplification: Methods Express (eds. Hughes and Laskin), from the Methods Express series. Scion Publishing Ltd., Oxfordshire, UK, 2005.

\section{INTRODUCTION}

T7-based linear amplification of DNA (TLAD) uses a linear amplification approach based on in vitro transcription (IVT) of template DNA by RNA polymerase from T7 phage. TLAD was designed for use with the ChIP-chip method (whereby DNA recovered from chromatin immunoprecipitation [ChIP] of cell lysate is used for subsequent analysis on DNA microarrays) and requires nanogram quantities of dsDNA to generate microgram amounts of amplified RNA. In Part I of the method, described here, a $3^{\prime}$ conserved end is added to the template dsDNA, using terminal deoxynucleotidyl transferase (TdT) tailing. The initial treatment with calf intestinal phosphatase (CIP) is optional but strongly recommended for removing 3' phosphate groups, because most genomic DNA fragmentation methods (i.e., sonication, micrococcal nuclease digestion, and certain restriction digests) produce a significant proportion of $3^{\prime}$ phosphate groups within the mixture of fragmented genomic DNA. This protocol is compatible with the presence of RNase $A$ and can be carried out immediately after digestion of RNA carried over from ChIP, without any intermediate clean-up step. The tailing reaction involves the addition of a short (20-40 nucleotide [nt]) poly(dT) tail to the template DNA. The included dideoxynucleotide acts as a tail terminator in the reaction mixture and is necessary to maintain a tight size distribution. This poly(dT) tail provides a conserved 3 ' element that permits the addition of a T7 promoter sequence in the subsequent second-strand synthesis step. IVT can then use this newly appended T7 promoter and linearly amplify the template dsDNA, producing amplified RNA product.

\section{RELATED INFORMATION}

Information about ChIP-chip and an overview of the TLAD method (including suggested controls and interpretation of results) is provided in Whole Genome Amplification by T7-Based Linear Amplification of DNA (TLAD): Overview (Liu et al. 2008a). The articles Whole Genome Amplification by T7-Based Linear Amplification of DNA (TLAD): II. Second-Strand Synthesis and In Vitro Transcription (Liu et al. 2008b) and Whole Genome Amplification by T7-Based Linear Amplification of DNA (TLAD): III. Sample Purification (Liu et al. 2008c) detail Parts II and III, respectively, of the TLAD method. See also Figure 1 for an overview of ChIP-chip. TLAD was originally described by Liu et al. (2003); a schematic of the method is shown in Figure 2.

\section{MATERIALS}

CAUTIONS AND RECIPES: Please see Appendices for appropriate handling of materials marked with $\langle$ ! $>$, and recipes for reagents marked with $<R>$. 


\section{Reagents}

CIP (2.5 units/ $\mu \mathrm{L})$ (New England Biolabs)

$<$ ! Cobalt chloride $(5 \mathrm{mM})$

$<\mathrm{R}>$ Dideoxynucleotide tailing solution (8\%)

Avoid subjecting the tailing solution to more than three freeze-thaw cycles, as additional freeze-thaw cycles will further degrade the nucleotides and reduce the efficiency of the reaction.

DNA template (double-stranded)

$<\mathrm{R}>$ Template dsDNA samples should be suspended in $\mathrm{H}_{2} \mathrm{O}, 1 \mathrm{X}$ TE buffer, or 1 X NEB Buffer 3 (which will not interfere with RNase digestion) and must not be denatured.

$<$ R $>$ EDTA (0.5 M, pH 8.0)

$\mathrm{H}_{2} \mathrm{O}$ (nuclease-free)

MinElute Reaction Cleanup kit (containing MinElute columns; Buffer ERC; Buffer PE; Buffer EB) (QIAGEN)

Add 95\% or 100\% RNase-free ethanol to Buffer PE before use; see manufacturer's protocol.

Mineral oil

NEB Buffer 3 (10X) (New England Biolabs)

$<!>10 X$ NEB Buffer 3 is typically supplied with the CIP enzyme and contains the following: $100 \mathrm{mM} \mathrm{NaCl} ; 50$ $\mathrm{mM}$ Tris- $\mathrm{HCl}$ ( $p H$ 7.9); $10 \mathrm{mM} \mathrm{MgCl} ; 1 \mathrm{mM} \mathrm{DTT}$.

Sodium acetate (3 M, pH 5.0) (optional; see Step 4)

TdT (20 units/ $\mu \mathrm{L}$ ) (New England Biolabs)

The New England Biolabs (NEB) recombinant enzyme is the preferred enzyme source. Enzyme derived from a natural source (e.g., Roche, typically derived from calf thymus) may have lot-dependent variation and may result in unpredictable or lowered IVT yields. The NEB recombinant enzyme is also preferred because the Roche recombinant enzyme typically yields $50 \%$ less amplification product with the volumes specified in this protocol.

TdT buffer (5X) (Roche)

$<$ ! >5X TdT buffer contains the following: 1 M potassium cacodylate; $125 \mathrm{mM}$ Tris- $\mathrm{HCl}(\mathrm{pH} 6.6) ; 1.25 \mathrm{mg} / \mathrm{mL}$ bovine serum albumin. Cacodylate is a methylated form of arsenic. While this form is less toxic than other forms of arsenic, it should still be treated as a toxic reagent and handled accordingly. Use waste disposal practices appropriate for your institution.

Note that this is the buffer supplied with the Roche TdT enzymes, not the buffer supplied with the NEB recombinant enzyme. The NEB TdT enzyme comes supplied with NEB Buffer 4 and $2.5 \mathrm{mM}$ cobalt chloride; the DTT in NEB Buffer 4 will precipitate the cobalt chloride and inhibit the reaction.

\section{Equipment}

\section{Microcentrifuge}

Microcentrifuge tubes (1.5-mL, nuclease-free)

Water bath or heat block preset to $37^{\circ} \mathrm{C}$

\section{METHOD}

Samples processed from the ChIP-chip method are typically quantified by one of several methods mentioned in Whole Genome Amplification by T7-Based Linear Amplification of DNA (TLAD): Overview (Liu et al. 2008a). The exact concentration of template dsDNA is not very critical for CIP treatment of samples (Steps 1-3). However, it is extremely important that the concentration of the template DNA be determined accurately for the tailing reaction (Steps 9-11).

\section{CIP Treatment of Samples with Terminal 3' Phosphate Groups}

When incorporating the ChIP-chip method (Fig. 1) with DNA linear amplification, some users might consider combining CIP treatment and RNase digestion to save time and labor. This can be done but may diminish yield, depending on the amount of undigested RNA present. If the amount of undigested RNA is large, the yield may drop by up to $50 \%$. This is likely due to the undigested RNA competing with template DNA for CIP activity, resulting in less efficient removal of the 3' phosphate groups. However, ChIP samples are unlikely to contain large amounts of carry-over RNA and are less likely to be affected by this issue. 


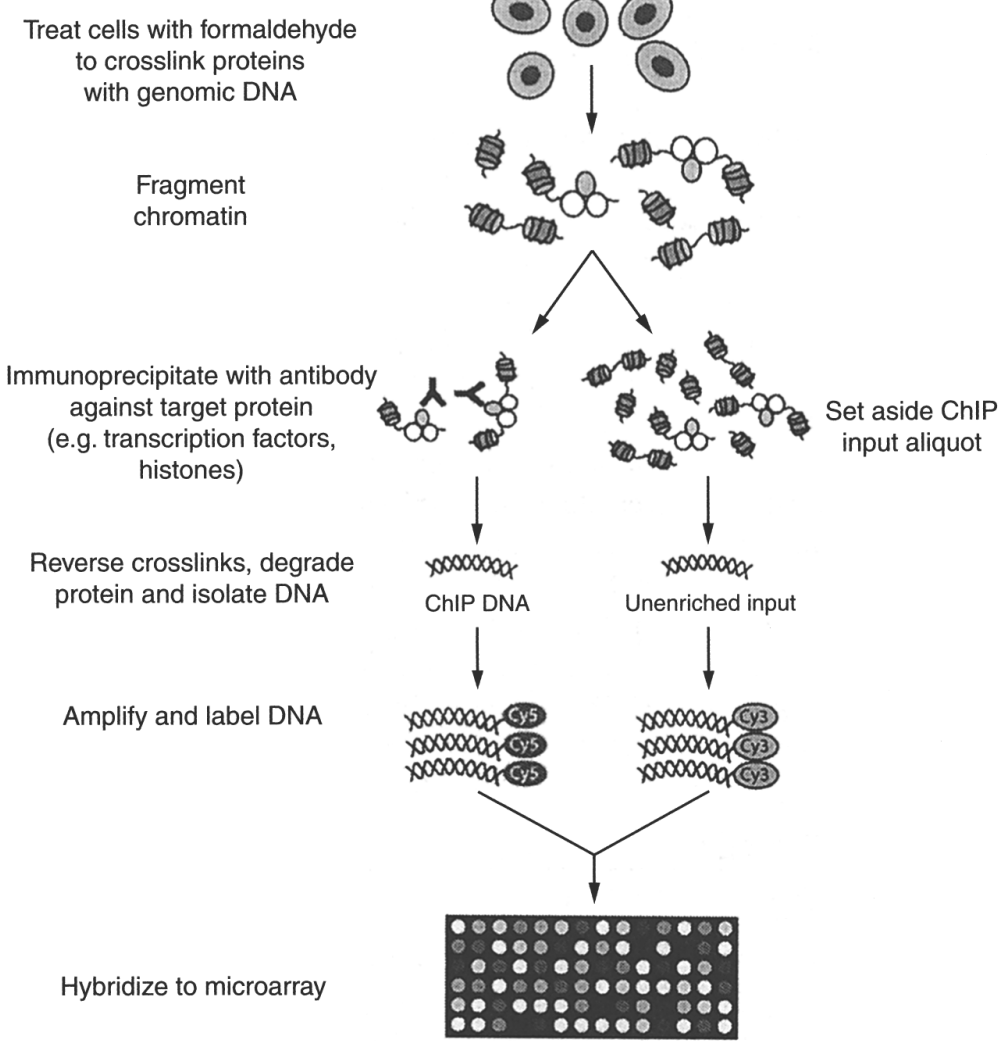

FIGURE 1. Schematic of the ChIP-chip method. Cells are first cross-linked with formaldehyde prior to lysis and DNA fragmentation. Following fragmentation, chromatin is incubated with antibodies and subsequently immunoprecipitated with Protein $A$ or Protein $G$ beads, which bind to the $F_{c}$ segment of the antibodies. Following elution from the beads, reversal of cross-links, and proteinase $\mathrm{K}$ digestion, ChIP samples are typically phenol-chloroform extracted, ethanol precipitated, and then treated with RNase A to eliminate RNA that has carried over from the immunoprecipitation. The ChIP samples and the unenriched input material are then amplified and labeled with fluorescent dyes. The ChIP sample is subsequently hybridized, along with the unenriched input, on a spotted microarray. (Reprinted with permission, (C) 2005 Scion Publishing Ltd.)

1. Prepare the CIP reaction mixture by combining, for every $10 \mu \mathrm{L}$ :

$1 \mu \mathrm{L}$

To $50 \mathrm{ng} / \mu \mathrm{L}$ maximum final concentration

$0.25 \mu \mathrm{L}$

To $10 \mu \mathrm{L}$ final volume
10X NEB Buffer 3 (1X final concentration)

Template DNA

CIP

$\mathrm{H}_{2} \mathrm{O}$

Each reaction can be scaled up to $100 \mu \mathrm{L}$ per tube; a typical reaction volume is 30-40 $\mu \mathrm{L}$. There should be no more than $500 \mathrm{ng}$ of template dsDNA per 10- $\mu \mathrm{L}$ reaction volume.

If the template DNA is suspended in NEB Buffer 3, the addition of 10X NEB Buffer 3 to the CIP reaction mixture is unnecessary.

2. Incubate the reaction for $1 \mathrm{~h}$ at $37^{\circ} \mathrm{C}$.

\section{Sample Purification Using MinElute Columns}

This method is based on the MinElute Reaction Cleanup kit protocol provided in the MinElute Handbook (supplied with the kit), except that the elution volume has been doubled from $10 \mu \mathrm{L}$ to $20 \mu \mathrm{L}$ because of the small amounts of DNA being purified at each step. Without this increase in elution volume, yields may drop by as much as 50\% (possibly because the MinElute columns have a decreased recovery yield for nanogram quantities of DNA).

3. Add Buffer ERC to each sample, according to sample volume: 


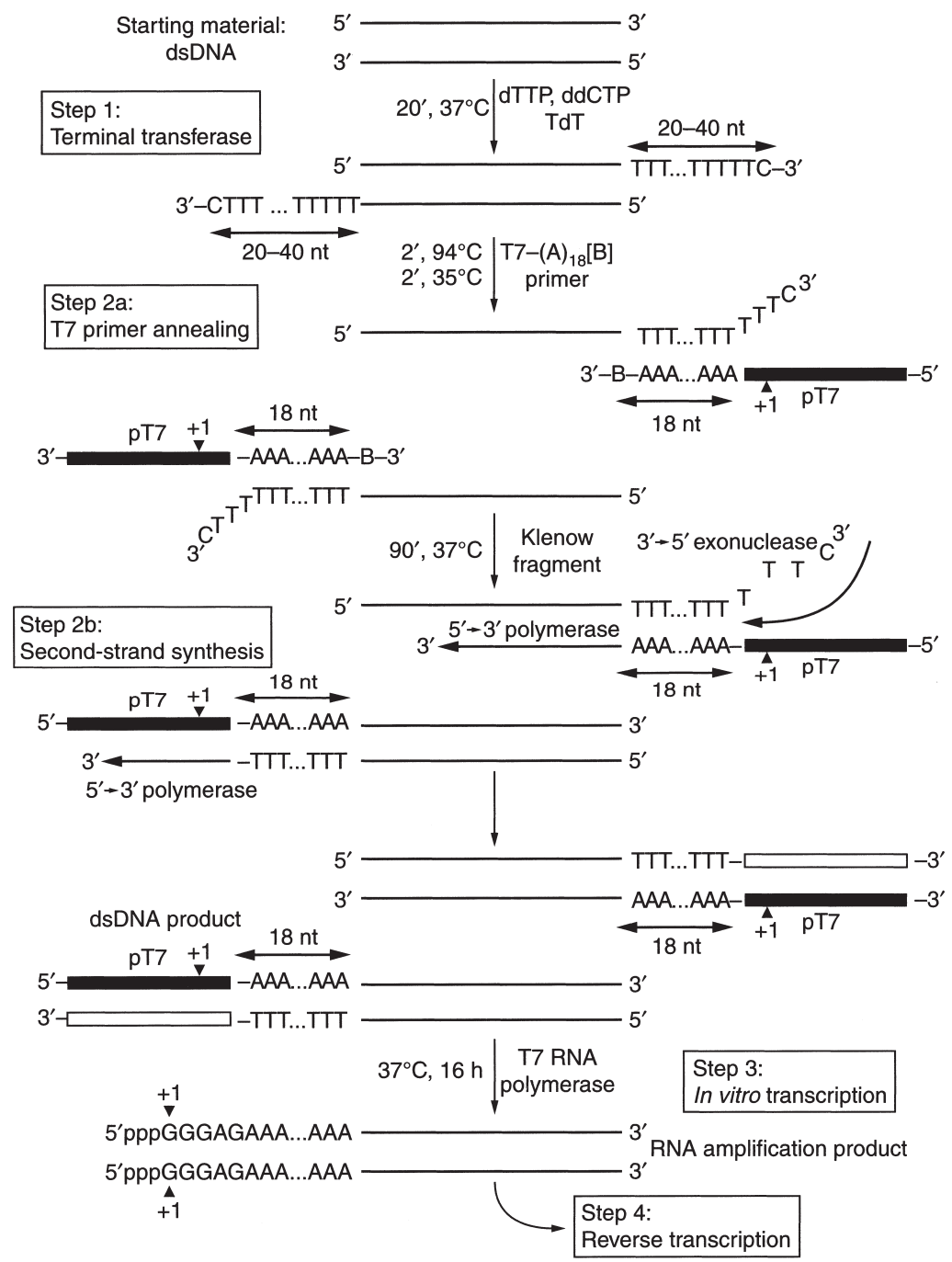

FIGURE 2. General strategy for the TLAD method. Starting with dsDNA template, TdT is used to add a poly(dT) tail to the $3^{\prime}$ ends of the template. This tail subsequently provides a conserved binding site for the annealing of T7 promoter (pT7)-poly(dA) primer adapters. Following subsequent second-strand synthesis using the large fragment of DNA polymerase I (Klenow fragment), one pair of dsDNA templates, with each pair member representing one of the two complementary strands of the dsDNA, is generated, with a T7 promoter at the $5^{\prime}$-end of the amplicon. In the subsequent IVT step, RNA is transcribed from this template in an isothermal reaction, producing an RNA amplification product consisting of both strands of the original dsDNA template in high microgram quantities. Note that each RNA strand will contain a short sequence from the T7 promoter and a poly(A) tract, 5' relative to the amplicon. (Reprinted with permission from Liu et al. [2003].)

i. In a sample of volume $20-100 \mu \mathrm{L}$, add $300 \mu \mathrm{L}$ of Buffer ERC and mix thoroughly.

ii. If the sample is in $<20 \mu \mathrm{L}$, make it up to $20 \mu \mathrm{L}$ with nuclease-free $\mathrm{H}_{2} \mathrm{O}$ and proceed as described in Step 3.i.

iii. If the sample is in $>100 \mu \mathrm{L}$, split the sample into aliquots $<100 \mu \mathrm{L}$, and process each aliquot in its own column as described in Step 3.i.

4. (Optional.) If the buffer color is orange or purple (i.e., pH greater than 7.5), add $10 \mu \mathrm{L}$ of $3 \mathrm{M}$ sodium acetate ( $\mathrm{pH}$ 5.0).

If the buffer is yellow, as is typically the case for this protocol, no additional sodium acetate is needed.

5. Apply the sample mixture to the MinElute spin column (sitting in a 2-mL collection tube) and centrifuge for $1 \mathrm{~min}$ at maximum speed in a microcentrifuge. 
6. Discard the flow-through and add $750 \mu \mathrm{L}$ of Buffer PE (which must contain ethanol). Centrifuge for $1 \mathrm{~min}$ at maximum speed in a microcentrifuge.

7. Discard the flow-through and centrifuge for $1 \mathrm{~min}$ at maximum speed in a microcentrifuge to dry the column.

8. Transfer the column to a fresh 1.5-mL nuclease-free microcentrifuge tube. Pipette $20 \mu \mathrm{L}$ (twice the manufacturer's suggested elution volume) of Buffer EB directly onto the column membrane. Leave it to stand for $1 \mathrm{~min}$ and then centrifuge for $1 \mathrm{~min}$ at maximum speed in the microcentrifuge to elute.

\section{Tailing Reaction with Terminal Transferase}

9. Prepare the $\mathrm{TdT}$ reaction mixture $(10-\mu \mathrm{L}$ reaction volume) by combining the following (TdT should be the last reagent added to the mixture):
$2 \mu \mathrm{L}$
$5 \mathrm{X}$ TdT buffer ( $1 \mathrm{X}$ final concentration)
$0.5 \mu \mathrm{L}$
Dideoxynucleotide tailing solution (8\%)
$1.5 \mu \mathrm{L}$
$5 \mathrm{mM}$ cobalt chloride $(0.75 \mathrm{mM}$ final concentration)
$5 \mu \mathrm{L}$
Template DNA from Step 8 (maximum $7.5 \mathrm{ng} / \mu \mathrm{L}$ final concentration)
$1 \mu \mathrm{L}$
TdT enzyme ( 2 units/ $\mu \mathrm{L}$ final concentration)

Add one to two drops of mineral oil to the top of the mixture to prevent evaporation during incubation. The maximum amount of template DNA is $\sim 1$ pmol of template molecules. This corresponds to an approximate maximum of $75 \mathrm{ng}$ for a mixture of template DNA with an average size range of $500 \mathrm{bp}$. The tested range is 2.5-75 ng of DNA per 10- $\mu \mathrm{L}$ reaction volume. Reaction volume may be scaled up accordingly for higher starting amounts, typically to $20 \mu \mathrm{L}$. For ChIP samples, an accurate concentration is critical-underestimation of the concentration will result in lowering the yield to as little as $5 \%-10 \%$ of the amount that is typical for this protocol, because much of the template DNA will not be tailed. If the samples cannot be accurately quantified, a 20$\mu L$ volume should be used.

10. Incubate the reaction for $20 \mathrm{~min}$ at $37^{\circ} \mathrm{C}$.

11. Stop the reaction by adding $2 \mu \mathrm{L}$ (per 10- $\mu \mathrm{L}$ reaction volume) of $0.5 \mathrm{M}$ EDTA ( $\mathrm{pH} 8.0$ ).

12. Clean up the reaction using the MinElute kit as described in Steps 3-8; elute in $20 \mu \mathrm{L}$ to achieve sufficient yields.

Minimize the amount of mineral oil carried over from the reaction; trace amounts are acceptable.

\section{TROUBLESHOOTING}

Troubleshooting information for this protocol and the related TLAD articles in this set (Parts II and III; see Related Information) is available in the Troubleshooting section of Whole Genome Amplification by T7-Based Linear Amplification of DNA (TLAD): III. Sample Purification (Liu et al. 2008c).

\section{ACKNOWLEDGMENTS}

C.L.L. is supported by a Graduate Research Fellowship from the National Science Foundation. S.L.S. is an investigator at the Howard Hughes Medical Institute. B.E.B. is supported by a K08 Development Award from the National Cancer Institute. This work was supported by a grant from the National Institute for General Medical Sciences.

\section{REFERENCES}

Liu, C.L., Schreiber, S.L., and Bernstein, B.E. 2003. Development and validation of a T7 based linear amplification for genomic DNA. BMC Genomics 4: 19 doi: 10.1186/1471-2164-4-19.

Liu, C.L., Bernstein, B.E., and Schreiber, S.L. 2008a. Whole genome amplification by T7-based linear amplification of DNA (TLAD): Overview. CSH Protocols (this issue) doi: 10.1101/pdb.top42.

Liu, C.L., Bernstein, B.E., and Schreiber, S.L. 2008b. Whole genome amplification by T7-based linear amplification of DNA (TLAD): II. Second-strand synthesis and in vitro transcription. CSH Protocols (this issue) doi: 10.1101/pdb.prot5003.

Liu, C.L., Bernstein, B.E., and Schreiber, S. L. 2008c. Whole genome amplification by T7-based linear amplification of DNA (TLAD): III. Sample purification. CSH Protocols (this issue) doi: 10.1101/pdb.prot5004. 


\title{
Whole Genome Amplification by T7-Based Linear Amplification of DNA (TLAD): I. CIP Treatment of Samples and Tailing Reaction with Terminal Transferase
}

\author{
Chih Long Liu, Bradley E. Bernstein and Stuart L. Schreiber
}

Cold Spring Harb Protoc; doi: 10.1101/pdb.prot5002

\begin{tabular}{|c|c|}
\hline $\begin{array}{r}\text { Email Alerting } \\
\text { Service }\end{array}$ & Receive free email alerts when new articles cite this article - click here. \\
\hline $\begin{array}{l}\text { Subject } \\
\text { Categories }\end{array}$ & $\begin{array}{l}\text { Browse articles on similar topics from Cold Spring Harbor Protocols. } \\
\text { Bioinformatics/Genomics, general (192 articles) } \\
\text { DNA Sequencing ( } 96 \text { articles) } \\
\text { Genetic Variation ( } 86 \text { articles) } \\
\text { Genetics, general (374 articles) } \\
\text { Genome Analysis (191 articles) } \\
\text { Genomic DNA (135 articles) } \\
\text { Genomic Libraries (66 articles) } \\
\text { Immunoprecipitation (75 articles) } \\
\text { Libraries (147 articles) } \\
\text { Libraries, general (113 articles) } \\
\text { Molecular Biology, general (1293 articles) } \\
\text { RNA (317 articles) } \\
\text { RNA, general (269 articles) }\end{array}$ \\
\hline
\end{tabular}

